\title{
The role of science in deepening democracy: the case for water in post-Apartheid South Africa
}

\author{
A TURTON*
}

\begin{abstract}
South Africa is a water constrained country with a complex history of resource capture and human rights abuses. Science, as practiced by the national science councils, could play a significant role in deepening our democracy. This paper explores two possible paradigms - one where science is divorced from the national constitution, and the other where our science is embedded in the national constitution. The paper argues that the latter approach would make our national science more relevant, but of necessity would embroil it in issues of historic legacy and therefore become "messy".

Keywords: Heroic engineering phase, cholera, Council for Scientific and Industrial Research (CSIR), water quality drivers: radiological, chemical and biological, National Nuclear Regulator (NNR), Tooth Fairy Project, Acid Mine Drainage (AMD), heavy metals, uranium, eutrophication, Cyanobacteria, xenophobia, Disciplines: Political science, hydropolitics, hydrology, history and water studies.
\end{abstract}

\section{Introduction}

South Africa is a water constrained country with a long and complex history of resource capture and human rights abuses (Turton, 2009). It is also the most diversified political-economy on the African continent, with a relatively sophisticated mix of different types of socio-economic activity ranging in scale from subsistence to the highly complex. This paper argues that science is a potential vehicle for the deepening of democracy by making a case for a National Water Quality Science, Technology and Policy Support Program (Turton, 2008a). This is done by contextualizing the public debate that arose in November 2008 when the author was banned from delivering the keynote lecture at the Biannual Conference of the Council for Scientific and Industrial Research (CSIR) entitled Science - Real and Relevant. This essay is an attempt to contextualize the debate that underpinned that banning, not as a form of justification of the merits of the author's case, but rather as an attempt to stimulate a national public discourse on the role of science in a fledgling democracy that is confronted by significant water constraints to future economic growth and development.

\section{The hydrological context to the debate}

South Africa has always been a semi-arid country even before the very first European explorers started to plot a route around the southern tip of Africa (Turton et al., 2004). The very first books on the subject of water

* Dr Anthony Turton, a social science researcher in the field of hydropolitics and water resource management, is currently a consultant in the private sector. Email: dr.anthony.turton@gmail.com 
as a factor limiting economic development were written in the 1870's by an author named Brown $(1875 ; 1877)$. His work described the aridity of the Cape and suggested the need for the development of infrastructure to overcome the problem. In 1886, Thomas Bain, a civil engineer in the Public Works Department, published his book Water-Finding, Dam-Making, River Utilization, Irrigation. The inspiration for this book came when he journeyed through the Karoo and pointed out to farmers how they could augment their water supply. He said, "... my hints were acted upon and in many instances successfully carried out". These "hints" referred to the utilisation of groundwater in the Karoo (Bain, 1886:3). He also gave advice in his book on the construction of dams (see Figure 1). This can be regarded as the birth of the early phase of the South African Hydraulic Mission. In this regard a national hydraulic mission can be defined as that discourse which underpins the quest for hydrological security as a foundation for economic development in a land that is fundamentally hydrologically insecure (or what some call being "hostage to hydrology" (Grey \& Sadoff, 2007)).

\section{Figure 1: Drawing of a dam made by Thomas Bain on 2 December 1885 showing details of an earth wall keyed into the river bank and a drawdown funnel (Turton et al., 2004:125). Original image made available by the Special Collection Section at the Academic Information Centre (AIC) (library) of the University of Pretoria.}

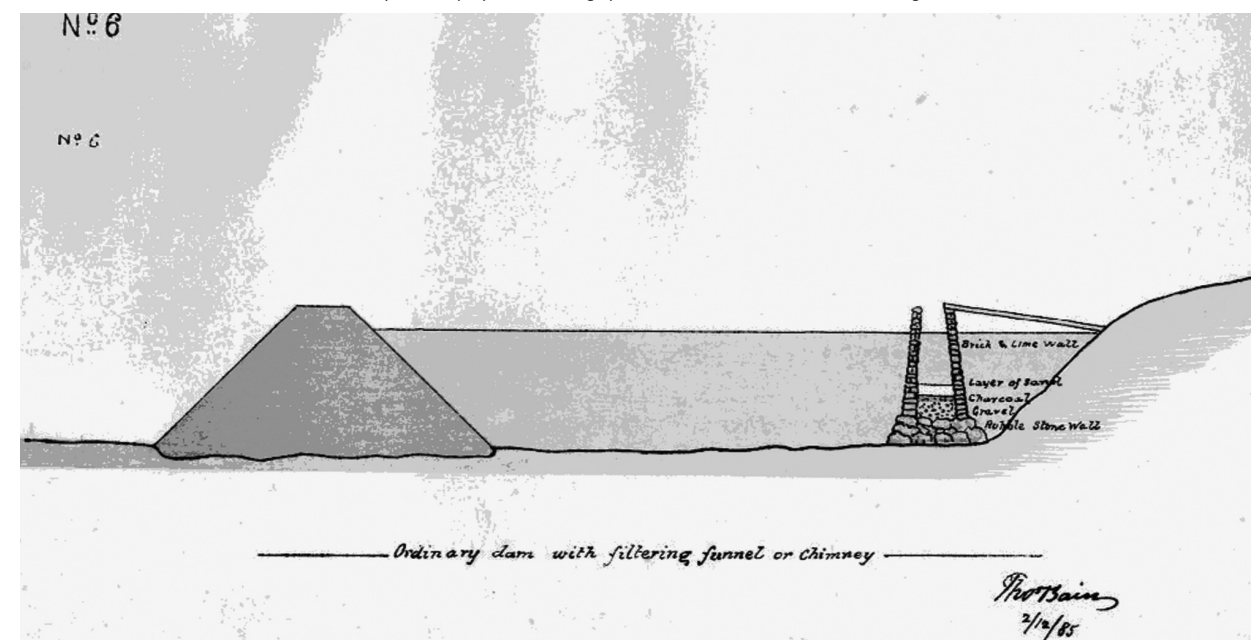

After South Africa became a Republic, a Commission of Inquiry into Water Matters was appointed in July 1966 by the State President, C.R. Swart (Turton et al., 2004). The objective of the commission was to inquire, report upon and submit recommendations on all aspects of water provision and utilisation within the Republic, the broad planning of policy regarding this "with due regard to the arrangements with neighbouring States relating to common water resources" (RSA, 1970:xii). The commission found that

(U)nless the essential steps are taken to plan the exploitation and augmentation of our water resources, to conserve and re-use our available supplies, and to manage and control our resources in the most efficient manner, serious shortages will be suffered somewhere before the close of the century (RSA, 1970:3). 
This can be regarded as a watershed year for South Africa in the context of water and development, because in effect this Commission of Enquiry into Water Matters projected the management of water resources to the highest level of strategic importance, giving rise to the Heroic Engineering Phase of the South African Hydraulic Mission (Turton et al., 2008a), which was accompanied by a proliferation of international treaties and agreements about transboundary river systems to which South Africa had a claim or a future strategic interest (Ashton et al., 2005). The concept of "heroic engineering" refers to that phase of the national hydraulic mission that seeks to overcome the obstacles to development that are placed there by nature, by co-producing hybrid aquatic ecosystems, through the development of infrastructure (Swyngedouw, 1999a; 1999b). In the contemporary language of sustainability science this is referred to as engineering a "social-ecological system" by virtue of the intimate links created between society and ecology as a result of this action (Burns \& Weaver, 2008).

The significance of this Heroic Engineering Phase of the South African Hydraulic Mission is that by 2004, South Africa had captured and allocated around $98 \%$ of the total national water resource (around 38 billion $\mathrm{m}^{3}$ / yr) at a high assurance of supply (NWRS, 2004), as shown in Figure 2. This places South Africa in a precarious situation, because in effect it means that the country has little surplus water on which to grow an economy, with a strong reliance on future technology to develop new water resources, either from recycling effluent, or from accessing increasing volumes of groundwater (see Figure 2). The difference between the volume of water currently available to sustain economic development \pm 38 billion $\mathrm{m}^{3} / \mathrm{yr}$ ); and the water needed to sustain projected economic development $( \pm$ 65 billion $\mathrm{m}^{3} / \mathrm{yr}$ ), is called "new water" for this purpose of this essay.

Figure 2: The availability of South Africa's surface water resources based on two developmental trajectories showing that even with lower water use the country has reached the limit of its surface water resource (CSIR, 2008a:19).

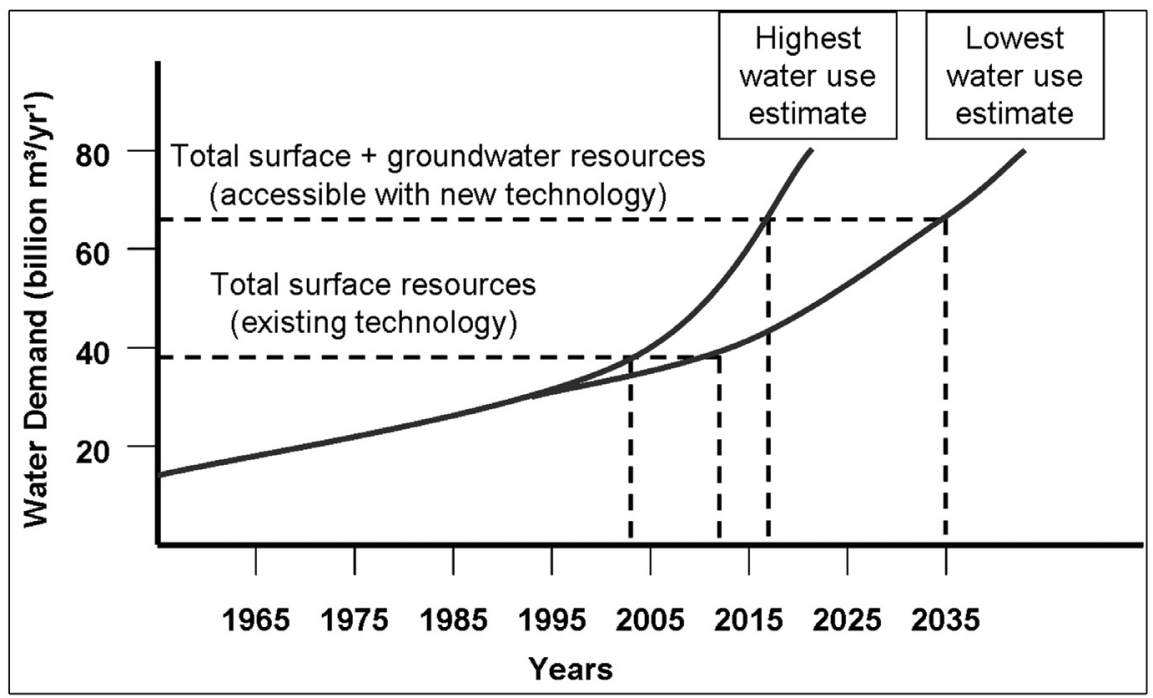


All manipulations of nature have unintended consequences however (Tenner, 1996), and the Heroic Engineering Phase of the South African Hydraulic Mission is no exception (Basson, 1995; Davies \& Day, 1998; Snaddon et al., 1999). In broad terms, one of these unintended consequences is manifest in the form of deteriorating water quality, driven largely by the loss of dilution capacity of over-allocated river systems. Thus, having solved the water quantity side of the national developmental equation (at least for the time being), the emphasis now shifts to the new challenge of water quality as a limiting factor to future economic growth and development.

\section{Water quality as an issue in South Africa}

South Africa currently faces a serious water quality challenge, both in the eyes of the public (Bega, 2008a; Coetzer, 2008; Tempelhoff, 2007; 2008) and scientists (Fatoki et al., 2001; Hattingh et al., 2006; Hattingh \& Claassen, 2008; Hobbs, 2008; Hodgson \& Krantz, 1998; IWQS, 1999; Kempster et al., 1996; Murray, 2006; Oberholster \& Ashton, 2008; Turton, 2008b; Van Vuuren, 2008; Winde, 2005). The cholera crisis in late 2008, coupled as it was with the collapse of the Zimbabwean economy and the massive out migration of people, often too ill to make the journey unassisted, became a media focal point. This coincided with the media interest in the banning of the keynote presentation at the CSIR Biannual Conference Science - Real and Relevant, thrusting the whole issue of science as applied to the management of water quality into the national spotlight (Bega, 2008b; Power, 2008).

The water quality problem can be broadly broken down into threats, or perceptions of threat, to human health. It is this perception of threat that makes the issue so emotive, because as long as people feel that they might be at risk, then human behaviour will be driven from this belief. In his capacity as a unit fellow at the CSIR responsible for Science, Engineering and Technology (SET) Leadership, the author made a detailed study of the full range of human health-related water quality drivers with a view to developing a robust scientific response (Turton, 2008a; 2008b). The manifestation of these water quality drivers can be broken down into three distinct generic categories: radiological, chemical and biological.

The radiological contamination of water is typically associated with radionuclide contamination downstream of gold mining areas. While the existence of radiological contamination in mine water has been known about for some time, this information has generally been a closely guarded secret, typically protected by a confidentiality agreement that prevented the information from entering the public domain. When South Africa became a democracy, the Constitution was strengthened by a Bill of Rights, making the withholding of information that had been previously classified more readily accessible to the public. Arguably the most notable of all research reports in terms of placing the radiological contamination of water into the public domain is the pioneering work done by Coetzee (1995) on the gold mining industry and by Toens et al., (1999) on groundwater. This research first became public domain just one year after South Africa became a democracy in 1994 and it spawned a plethora a new work in this field (CSIR, 2008b; Coetzee et al., 2002a; 2002b; 2005; 2006; IWQS, 1999; Wade et al., 2002). Of this the most relevant was the document that became known as Report 1214 (Coetzee et al., 2006). This 
report created immediate public interest once released, with the first print run rapidly being sold out. Concerned at the possible consequences of the findings in Report 1214, the National Nuclear Regulator immediately commissioned a study, which came to be known as the Brenk Report (NNR, 2007). The Brenk Report, which has never been made available to the public in full text, confirmed the findings of Report 1214, suggesting that the extent of the problem might have even been underreported. In response to this and cognizant of the CSIR parliamentary mandate, the author developed a Project Concept Note that sought to launch a high confidence study into the health implications of off-mine populations that might have been exposed to radioactivity or heavy metals from mine water (CSIR, 2008). This proposed study became known as the Tooth Fairy Project (Smillie, 2008), because it was based on a highly successful program launched in the United States of America in the 1950's that made use of human deciduous teeth as a source of data for possible evidence of radiological exposure over time. This classic American study was known as the St Louis Baby Tooth Survey, which became a significant research program yielding masses of longitudinal data on human health and the environment (Mongillo \& Booth, 2001) (also see http://beckerexhibits.wustl.edu/dental/articles/babytooth.html).

The chemical contamination of water is far less specific in its geographic spread, because it arises from a variety of sources, both point and diffuse. The common element in this form of contamination is the threat it poses to human health. A specific sub-set of this is what is known as Endocrine Disrupting Chemicals (EDCs), which have the potential to alter the normal functioning of the endocrine system (Genthe \& Steyn, 2008). The endocrine system is responsible for guiding the development, growth, reproduction and behaviour of both humans and animals (IPCS, 2002), so a typical manifestation is disruption to the gonads, a shift in a population from male to female, or the development of a foetus with both male and female organs. A significant component of the science underpinning our understanding of endocrine disrupting effects is the fact that that these substances have transgenerational capabilities (IPCS, 2002, American Chemical Society, 1998). This implies that not only can these adverse effects result from exposure of either parent prior to conception, but it can also result from exposure of the developing embryo in utero, or from exposure of the progeny after birth (Daston et al., 2003).

This means that EDCs are extremely important forms of chemical contamination, specifically in the context of a developing country with a high level of HIV/AIDS and a limited dilution capacity resulting from over-allocation of existing water resources (Rascher et al., 2009; Turton, 2008b). Dalvie et al., (2003) reports on some effects of chemical contamination from the agricultural sector. The return flow of agrochemicals into stressed river systems has also been documented (Awofolu \& Fatoki, 2003). The unintended consequences of attempts to control malaria through aerial spraying results in impaired human semen quality (Aneck-Hahn et al., 2007) and babies being born with significant urogenital defects (Bornman et al., 2005). The loss of dilution capacity in our national rivers, combined with failing sewage treatment works pose a specific chemical-related risk in the form of oestrogen, which disrupts the endocrine system and unleashes a process of androgyny. Work in this regard has been done by Aneck-Hahn et al., (2002) Barnhoorn et al., (2004), Bornman et al., (2007) and Slabbert et al., 
(2007a; 2007b). Considerable effort has been made to develop a coherent national research response to this form of contamination (Offringa et al., 2007). Research has had mixed results however, given the inherent complexity of translating effects observed in animals into possible effects in humans, specifically when it comes to androgyny (Daston et al., 2003; WSE, 2008). The impact of this exposure on a population with a high level of HIV/AIDS is not really known with any certainty (Rascher et al., 2009), making such research a matter of strategic priority.

A distinct sub-set of this category of chemical contamination is Acid Mine Drainage (AMD). In a certain sense, South Africa finds itself in a similar position to that which faced Germany after reunification in 1990 (Hobbs, 2008). The lignite and uranium mining activities practised in the Federal States of Saxony and Thuringia in the former East Germany (German Democratic Republic), as well as the chemical industries in the Bitterfeld area, left behind a devastated landscape and environment. The responsibility for the rehabilitation of these legacies fell to the Federal Republic and the respective Federal States. Acid mine water is a pernicious contaminant that not only sterilises its receiving environment, but also carries trace elements such as heavy metals and radionuclides in concentrations that are potentially hazardous to all forms of life (Hobbs, 2008). Whilst manageable in small quantities, the potential volume resulting from more than 100 years of gold and coal mining is alarming. For example, the volume of acid mine water currently coming to surface in the West Rand goldfield near Krugersdorp is sufficient to fill at least 10 Olympic-size swimming pools $\left(2,500 \mathrm{~m}^{3}\right.$ each) every day (Hobbs, 2008).

The daily salt load in this water is equivalent to almost 140 tons (Hobbs, 2008). These values can readily be multiplied tenfold to obtain an order of magnitude (and probably still conservative!) number for the entire Witwatersrand Basin comprising five goldfields (Hobbs, 2008). In addition to the West Rand goldfield already mentioned, these are the East Rand, the Central Rand, the Far West Rand and the KOSH goldfields. By comparison, the Olifants River catchment witnesses roughly double the West Rand Basin values from defunct coal mines in the Witbank coalfield (Hobbs, 2008). The situation in the other coalfields (e.g. Highveld and Ermelo) located in the catchment of the Vaal Dam is still largely unknown, but some localized work has been done (Bell et al., 2001). The potential volume of poor quality mine water threatens to significantly reduce the utility of the already stressed freshwater resources of the economic engine-room of the country (Hobbs, 2008). Furthermore, the impact of mine water quality on humans is largely unknown and has not yet been studied in South Africa (Adler et al., 2007). A proposal that was submitted to the Water Research Commission to address this deficiency (CSIR, 2008) was unfortunately rejected, so the state of knowledge around this crucial area is still very weak.

The biological contamination of water is typically the result of increased levels of nutrients downstream of sewage works that are malfunctioning, or in the case of cholera, a lack of proper sanitation services. In South Africa this usually manifests as eutrophication or the proliferation of algal biomass in the presence of elevated levels of nutrients (Harding \& Paxton, 2001; Oberholster et al., 2008). In the context of eutrophication, cyanobacteria are a group of diverse gram-negative prokaryotes and are one of the earth's most ancient life forms (Oberholster, 2008). Evidence of their existence on earth, derived from fossils records, encompasses a 
period of some 3.5 billion years (Oberholster et al., 2005). Cyanobacterial blooms have become an increasing problem in South African freshwater bodies (Harding \& Paxton, 2001; Oberholster \& Ashton, 2008).

Cyanobacteria produce some of the most potent toxins known and have no known antidotes. Work done by the CSIR in the 1980's showed that the molecular structure of some cyanotoxin is similar to that of snake venom (CSIR, 1984). These biotoxins fall into three categories namely neurotoxins, hepatoxins and lipopolysaccharides (Oberholster, 2008). The biotoxins in the first two groups can produce severe reactions in animals and humans, while the third group appears to be less virulent (Oberholster et al., 2005). However, the latter have been less intensively studied. Any release of these biotoxins into surrounding water can present a significant hazard to humans and the ecosystem (Oberholster et al., 2005). The existence of gastrointestinal disorders linked to the ingestion of cyanobacterial biotoxins, as well as the chronic risks posed by hepatoxins, make these toxins a serious threat to human health when they are present in drinking water supplies. A survey conducted in South Africa between 2004-2007 by Botha and Oberholster, used RT-PCR and PCR technology to distinguish Microcystis strains bearing the mcy genes, which correlate with their ability to synthesize the cyanobacterial biotoxin microcystin, revealed that $99 \%$ of South Africa's major impoundments contain toxic strains of Microcystis (Botha \& Oberholster, 2007; Oberholster \& Botha, 2007). Insofar as the bulk provision of raw potable water is concerned, problems posed by cyanobacterial biotoxins in South Africa are not yet of national crisis status (Oberholster, 2008). However, the biotoxin concentrations of cyanobacteria in major impoundments in Gauteng are so high, that a regional crisis exists if it is compared to impoundments of countries aboard (Oberholster et al., 2008). While no confirmed human death has yet been attributed to these biotoxins produced by cyanobacteria in South Africa, acute poisoning of humans has been reported from South America, Africa and Australia (Oberholster, 2008).

The majority $(80 \%)$ of rural communities in South Africa rely on surface water as the main source of domestic water (Fatoki et al., 2001). Therefore, it can be postulated that chronic exposure to low levels of cyanotoxins by people that live in rural areas, who have compromised or suppressed immune systems due to HIV/AIDS and possibly also suffer from other communicable and poverty-related diseases such as Tuberculosis, may experience serious social and economic consequences as a result of cyanotoxins (Oberholster, 2008).

Furthermore, common symptoms of cyanotoxin poisoning (diarrhoea, vomiting, stomach pains) are similar to the symptoms of gastrointestinal illness caused by bacteria, as well as other viral and protozoan infections and are thus not immediately linked to cyanotoxin poisoning (Falconer, 1998 ; 2005). While the long-term impact on the health of South Africans who have been exposed to low doses over a long period of time is unknown by virtue of the absence of definitive research on the subject (Oberholster, 2008), a study to assess the chronic human health hazards caused by the biotoxins of cyanobacteria toxin ingested over long periods, such as might occur through drinking water from untreated sources, was undertaken on human lymphocytes in vitro. It was found that the cyanobacterial toxins produced more chromosome damage than did benzene and sodium arsenite (Pitois et al., 2000). 
A study conducted by Humpage et al., (2000) indicated that microcystins from a cyanobacterial extract provided in drinking water to rats increased the area of aberrant crypt foci in the colon, suggesting that microcystins promote preneoplastic colonic lesions (Oberholster, 2008). It has also been shown that microcystins are potent tumour promoters (NishiwakiMatushima et al., 1991) and there is an indication that they might also act as tumour initiators (Ito et al., 1997). Epidemiological studies have suggested that microcystins are an important risk factor for the high incidence of primary liver cancer in certain areas of China, where people have consumed pond-ditch and river water contaminated with low levels (within the range of 0.09-0.46 $\mu \mathrm{g} / 1$ ) of microcystins (Ueno et al., 1996). It has also been shown that bathing and showering in water containing cyanobacterial cells can results in allergic reactions resembling hay fever, asthma and skin, eye and ear irritation. Oberholster (2008) notes that a new emerging problem includes the production of â- $\mathrm{N}$ methylamino-L-alanine (BMAA), a neurotoxic amino acid which is a possible cause of parkinsonism-dementia in humans and which is produced by all known groups of cyanobacteria.

\section{The role of science in deepening democracy}

With the water quality challenges noted above, it is clear that South Africa is in a critical position at present. Left unmanaged, two possible consequences can be anticipated. These are a gradual decline into a quagmire of social unrest and the general under-performance of the national economy as water constraints limit future growth potential.

With respect to the first aspect - the possibility of water quality issues driving social unrest - there is no hard empirical evidence that makes a compelling argument. Having noted this however, there are bits of evidence that suggest we should start to take this issue a lot more seriously. In this regard there are three elements of a potential argument that water quality can drive future social instability. The first is the general literature on water and conflict, which has shown that while wars between states over water are highly unlikely, water does have the capacity to amplify and aggravate existing sub-national tensions (Ashton, 2000; 2002; Ashton \& Turton, 2008; Gleick, 1993; 1994; Homer-Dixon, 1994; 1999; Wolf, 1998; 1999; 2006; Wolf et al., 2003). The second is the small but convincing literature on resource-related conflict as it pertained specifically to South Africa (Johnston \& Bernstein, 2007; Percival \& Homer-Dixon, 1998; 2001). Of this, the most significant is undoubtedly the case of Khutsong (Merafong), where a convincing case has been made by Johnston \& Bernstein (2007) that while the violence in that municipality has many causes, the issue of water accessibility and perceived nepotism and patronage in terms of service delivery were key drivers in their own right. The third is the as-yet unresearched issue of xenophobic violence that took place in South Africa in 2008. Media reports indicate the extreme nature of this violence (Johnston \& Wolmarans, 2008).

Similar reports suggest that failing economic standards were a potential driver of the violence (Sibanda, 2008). The unpredictability of this violence, coupled with the extreme nature of the event where humans were set alight by angry mobs, suggests that such violence could be triggered in future if public perceptions of failing health arising from deteriorating water quality are not taken seriously. To this end a testable research 
hypothesis has been suggested - the propensity to resort to mass violence increases when public expectations exceed the capacity of the state to deliver - and the question has been posed as to whether this type of anger could be unleashed in response to perceptions of deteriorating public health arising from declining water quality (Turton, 2008a). In this regard the events currently unfolding in Zimbabwe will provide rich research data as thousands succumb to cholera through collapsing water reticulation infrastructure (a situation also present in South Africa, but as yet to a less catastrophic extent).

This leads to a logical question - what role could science play in deepening democracy in South Africa? Here we have two poles to the argument. The one pole is centred on science as a commercialized entity selling itself to paying clients as a professional service. The opposite pole is centred on science as a public domain entity providing services of a scientific nature that are perceived by the public to be useful. These two poles need to be unpacked a little in order to better understand their relevance in contemporary South Africa. This will be done by using the CSIR as a case study.

The CSIR is a parastatal body that was created by an Act of Parliament the Scientific Research Council Act - in 1945. The first meeting of the CSIR Council (the governing body) on 8 October 1945 was addressed by Jan Smuts in his capacity as Prime Minister of the Union of South Africa, where he said:

The time has come when we must tackle our own ... problems which lie before in South Africa. We must develop our own scientific handling of those problems. ... Science has come forward in gigantic strides and more and more everyone is beginning to feel that scientific research is a matter of vital importance (Kingwill, 1990:13).

This gave rise to a national science capability that was deployed in the national interest with the intention of developing the economy at the fastest possible rate. As South Africa moved towards a democracy in 1994, the CSIR was given a new mandate. Section 3 of the Scientific Research Council Act (Act 46 of 1988 as amended by Act 71 of 1990) stipulates that the objective of the CSIR is to:

(F)oster, in the national interest and in fields which in its opinion should receive preference, industrial and scientific development, either by itself or in co-operation with principals from the private and public sectors, ... to contribute to the improvement of the quality of life of the people of the Republic.

Key elements of this mandate are therefore the following:

- The national interest (however that may be defined).

- The improvement of the quality of life of the people of South Africa.

- The role of industry and science in national development.

- Partnerships with both (or either) the public and private sectors.

- The discretion by scientists to nominate work which they believe would help to attain the above objective. 
Science as a commercialized entity is in essence what the CSIR does at present. Around $35-40 \%$ of its income stream comes from Parliament, which is insufficient to sustain the CSIR as a viable entity. This means that the shortfall has to be made up by selling scientific services to both the public and private sectors. In an assessment of the consequences of this so-called mixed income model, two senior CSIR officials came to the conclusion in 2006 that this model is deeply flawed (Walwyn \& Scholes, 2006).

A direct correlation was found to exist between the flow of Parliamentary grant money and staff turnover. The conclusion was drawn that contract income does not retain science capacity within the institution, which has significant consequences for South Africa if left unchecked. An alarming trajectory was found where staff numbers peaked in the mid1980 s at around 5,000 and dropped off to just above 2,000 in 2006 (see Figure 3). This has obvious strategic significance if one considers the vital role of science and technology in unlocking the so-called "new water" needed to sustain future economic development presented in Figure 2.

Figure 3. Trends in funding and staff turnover at the CSIR (Walwyn \& Scholes, 2006:241). Program-styled funding builds national capacity but contract-driven funding does not retain that capacity.
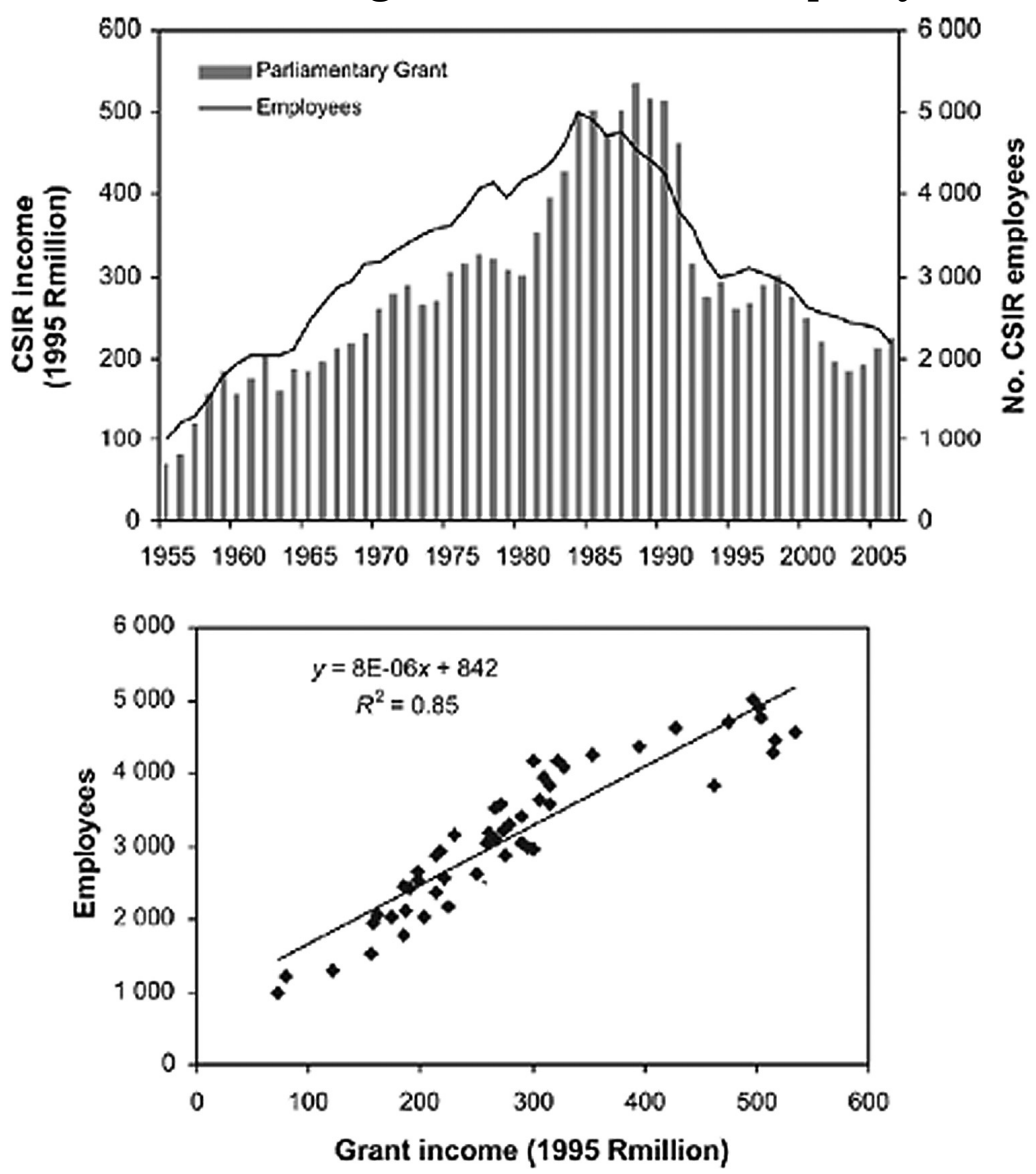
In response to this, in his capacity as a Unit Fellow at the CSIR, the author developed a case for returning to the grant funding that had built the national scientific capacity before 1985 (Turton, 2008a). Noting that the findings of Walwyn \& Scholes (2006) were consistent with his own observations, and suggesting that this would have catastrophic effects for South Africa as a whole if left unchecked, the author proposed a National Water Quality Science, Technology and Policy Support Program, based largely on the scientific evidence presented above. This mooted Program would embed the national scientific capacity of the CSIR in the constitution of the country. In so doing the national interest would be served by deepening democracy and dealing with the many complex issues related to more than a century of resource capture and human rights abuse. The act of deliberately placing our national science capability in the public domain would give access to public funding, thereby making the CSIR more financially sustainable, but also more accountable to the legitimate representatives of the citizens of South Africa (Parliament). It would also mean that the scientists in the CSIR would become a national asset, which could now be redeployed in a concerted capacity building exercise where Principal Scientists could become Extraordinary Professors of the various universities, thereby transferring skills in critical areas of national importance. The downside of this deliberate act is that it would open the plethora of legacy-related issues that have been left unmanaged. This becomes potentially messy, but the payoff for the CSIR as an institution is that it would then become relevant to the country in its current phase of post-apartheid reconstruction and redistribution of privilege.

\section{Discussion}

The fact that South Africa is water constrained is beyond any reasonable doubt. The implications that this has for future economic growth and prosperity is not as clear, but one can say with considerable confidence that future developmental aspirations will not be met unless these water constraints are effectively managed. Part of that management is the mobilization of the national scientific capacity needed to make the paradigm shift called for in Figure 2 where the national water demand of 38 billion $\mathrm{m}^{3} / \mathrm{yr}$ in 2010 is grown to 65 billion $\mathrm{m}^{3} / \mathrm{yr}$ in 2035 (assuming a low water use scenario is possible to sustain the level of economic development needed to maintain social stability). Current indications are that the national science councils will be unable to rise to the occasion, if the trajectory presented in Figure 3 is not drastically altered by a new funding model underpinned by the massive investment of public money. In the absence of this public domain science, then the private sector will have to be embraced in an effort to mobilize the technology needed to meet the demand for water that future economic growth will entail (see Figure 2). This raises the prospect of "new water" as a pressing national priority, along with the role of both the private and public sector in making this happen.

The question is still open - what role could science play in deepening democracy in South Africa? If the national science councils are forced to continue as commercialized entities, then they run the very real risk of being hijacked by private interests intent on maintaining the status quo in the country. This will lock in existing inequities and could potentially undermine the stability of our fledgling democracy. On the 
other hand, if our national science councils are given robust grants and a focussed research agenda that meets the national interests as broadly defined, then science could play a vital role in addressing past inequities and helping with the transition to a more stable society in which the core values of democracy are deeply entrenched.

\section{Conclusion}

Science has always played a major role in the development of South Africa. It was the national science capacity in the 1950 s that made South Africa a world leader in oil from coal and deep-level mining. It was the same national science capacity in the 1980s that enabled the South African government to engage in regional wars of considerable intensity and also to withstand the otherwise debilitating effects of comprehensive economic sanctions. Today it could be the same national science capacity that could help to entrench social equity and a new form of sustainable development, thereby building a more just society as envisaged by our national constitution. Thus far the latter has not occurred and our national science capacity is dwindling at an alarming rate. The pivotal question is the positioning of a major national science council like the CSIR, either as an entity separate from the constitution and thus largely irrelevant to society but potentially lucrative to the narrow interests of those that can afford their services; or as an entity embedded in the constitution and thus relevant to the broader base of society, but potentially mired in the many complex issues arising from our historic legacy. This debate is an important one and should be waged in the public domain being led by scientists with a moral conscience and a desire for a just society.

\section{Bibliography}

Adler, R.A., Claassen, M., Godfrey, L. and Turton, A.R. (2007). Water, mining and waste: an historical and economic perspective on conflict management in South Africa. The Economics of Peace and Security Journal. Vol. 2. No. 2. Pp. 33-41.

Aneck-Hahn, N.H., de Jager, C., Bornman, M.S. \& du Toit, D. 2002. Oestrogenic activity using a recombinant yeast screen assay (RCBA) in South African laboratory water sources. Water SA. (31)2. Pp. $253-256$.

Aneck-Hahn, N.H., Schulenburg, G.W., Bornman, M.S., Farias, P \& de Jager C. 2007. Impaired Semen Quality Associated with Environmental DDT Exposure in Young Men Living in a Malaria Area in the Limpopo Province, South Africa. Journal of Andrology. (28)3 Pp 423-434.

Ashton, P.J. 2000. Southern African Water Conflicts: Are They Inevitable or Preventable? In Solomon, H. \& Turton, A.R. (Eds.) Water Wars: Enduring Myth or Impending Reality? African Dialogue Monograph Series No. 2. Pp 65-102. Durban: ACCORD Publishers.

Ashton, P.J. 1996. Water Quality. In Shackleton, L.Y., Lennon, S.J. \& Tosen, G.R. (Eds.). Global Climate Change and South Africa. Cleveland: Environmental Science Association. 
Ashton, P.J. 2002. Avoiding Conflicts over Africa's Water Resources, Ambio 31(3): 236-242.

Ashton, P.J. \& Turton, A.R. 2008. Water and Security in Sub-Saharan Africa: Emerging Concepts and their Implications for Effective Water Resource Management in the Southern African Region, in Brauch, H.G., Grin, J., Mesjasz, C., Behera, N.C., Chourou, B., Spring, U.O., Liotta, P.H. and Kameira-Mbote, P. (Eds.) Globalisation and Environmental Challenges: Reconceptualizing Security in the $21^{\text {st }}$ Century. Berlin: Springer Verlag. Chapter 56.

Ashton, P.J., Earle, A., Malzbender, D., Moloi, M.B.H., Patrick, M.J. \& Turton, A.R. 2005. A Compilation of all the International Freshwater Agreements entered into by South Africa with other States. Water Research Commission Report No. 1515/1/06. Pretoria: Water Research Commission (WRC).

Awofolu, R.O. \& Fatoki, O.S. 2003. Persistent organochlorine pesticide residues in freshwater systems and sediments from the Eastern Cape, South Africa. Water SA. (29)3. Pp. 323 - 320.

Bain, T. 1886. Water-finding, Dam-making, River Utlization, Irrigation. Cape Town: Saul Solomon \& Co.

Barnhoorn, I.E.J., Bornman, M.S., Pieterse, G.M. \& van Vuren, J.H.J. 2004. Histological evidence of Intersex in feral sharptooth catfish (Clarias garipinus) from an estrogen-polluted water source in Gauteng, South Africa. Environmental Toxicology. (19)6. Pp. 603608.

Basson, M.S. 1995. South African Water Transfer Schemes and their Impact on the Southern African Region, in Matiza, T., Craft, S. \& Dale, P. (Eds.) Water Resource Use in the Zambezi Basin. Proceedings of a Workshop held in Kasane, Botswana, 28 April - 2 May 1993. Gland, Switzerland: IUCN.

Bega, S. 2008(a). South African Water Quality is Fast Deteriorating. Pretoria News. 22 September 2008.

Bega, S. 2008(b). Water Expert Suspended. Blog online at http:// www.environment.co.za/topic.asp?TOPIC_ID $=2179$.

Bell, F.G., Bullock, S.E.T., Hälbich, T.F.J. and Lindsay, P. 2001. Environmental impacts associated with an abandoned mine in the Witbank coalfield, South Africa. International Journal of Coal Geology. Vol. 45. Pp. 195-216.

Bornman, M.S., Delport, R., Becker, P., Risenga, S.S. \& de Jager, C.P. 2005. Urogenital birth defects in neonates from a high-risk malaria area in Limpopo Province, South Africa. Epidemiology. (16)5. S126 - 127.

Bornman, M.S., van Vuren, J.H., Bouwman, H., de Jager, C., Genthe, B \& Barnhoorn, E.J. 2007. The use of sentinal species to determine the endocrine disruptive activity in an urban nature reserve. WRC Report No. 1505/1/07. Pretoria: Water Research Commission.

Botha, A-M,. \& Oberholster, P.J. 2007. PCR-Based Markers for Detection and Identification of Toxic Cyanobacteria. WRC Report No. K5/1502/ 
01/07. Pretoria: Water Research Commission.

Brown, J.C. 1875. Hydrology of South Africa; or Details of the Former Hydrographic Conditions of the Cape of Good Hope, and causes of its Present Aridity, with Suggestions of Appropriate Remedies for this Aridity. London: Kirkaldy.

Brown, J.C. 1877. Water Supply of South Africa and the Facilitation for the Storage of It. Edinburgh: Oliver Boyd, Tweedale Court.

Burns, M.J. \& Weaver, A.v.B. (Eds.) 2008. Advancing Sustainability Science in South Africa. Stellenbosch: Stellenbosch University Press.

Coetzee, H. 1995. Radioactivity and the Leakage of Radioactive Waste Associated with Witwatersrand Gold and Uranium Mining. In Merkel, B. J., Hurst S., Löhnert E.P. \& Struckmeier W. (Eds.) Proceedings Uranium Mining and Hydrogeology 1995, Freiberg, Germany: GeoCongress 1. - 583 S.; Köln (von Loga; ISBN 3-87361256-9).

Coetzee, H., Wade, P., Ntsume, G. \& Jordaan, W. 2002. Radioactivity Study on Sediments in a Dam in the Wonderfonteinspruit Catchment. Pretoria: Department of Water Affairs and Forestry.

Coetzee, H., Wade, P. \& Winde, F. 2002. Reliance on Existing Wetlands for Pollution Control Around the Witwatersrand Gold/Uranium Mines in South Africa - Are They Sufficient? In Merkel, B.J., Planer-Friederich, B. \& Wolkersdorfer, C. (Eds.). 2002. Uranium in the Aquatic Environment. Berlin: Springer. Pp. 59-65.

Coetzee, H., Venter, J. \& Ntsume, G. 2005. Contamination of Wetlands by Witwatersrand Gold Mines - Processes and the Economic Potential of Gold in Wetlands. Council for Geosciences Report No. 2005-0106. Pretoria: Council for Geosciences.

Coetzee, H., Winde, F. \& Wade, P.W. 2006. An Assessment of Sources, Pathways, Mechanisms and Risks of Current and Potential Future Pollution of Water and Sediments in Gold-Mining Areas of the Wonderfonteinspruit Catchment. WRC Report No. 1214/1/06. Pretoria: Water Research Commission.

Coetzer, P. 2008. Water Management under Pressure: South Africa Might be Facing a Water Contamination Crisis. Achiever. 1 March 2008.

CSIR. 1984. Annual Report of the National Chemical Laboratory. CSIR Special Report CHEM 265. Pretoria: Council for Scientific and Industrial Research (CSIR).

CSIR. 2008(a). Is the Glass Half Full or Half Empty? Science Scope, Vol. 3: No. 1 ; 18-19.

CSIR. 2008(b). High Confidence Study of Children Potentially Affected by Radionuclide and Heavy Metal Contamination Arising from the Legacy of Mine Water Management Practices on the Far West Rand of South Africa. Project Concept Note, dated 26/2/2008. Pretoria: Council for Scientific and Industrial Research (CSIR).

Dalvie, M.A., Cairncross, E., Solomon, A. \& London, L. 2003. Contamination of rural surface and ground water by endosulfan in farming areas of the Western Cape, South Africa. Environ Health, (2)1. Pp. 1. 
Daston, G.P., Cook, J.C., \& Kavlock, R.J. 2003. Uncertainties for Endocrine Disrupters: Our View on Progress. Toxicological Sciences. (74)2. Pp. $245-252$.

Davies, B.R. \& Day, J. 1998. Vanishing Waters. Cape Town: University of Cape Town Press.

Falconer, I.R. 1998. Algal toxins and human health. In Hrubec, J. (Ed.), Handbook of Environmental Chemistry, Volume 5 (Part C). SpringerVerlag, Berlin, pp. 53-82.

Falconer, I.R. 2005. Cyanobacterial Toxins of Drinking Water Supplies: Cylindrospermopsins and Microcystins. CRC Press, Florida, USA.

Fatoki, O.S., Muyima, N.Y.O. \& Lujiza, N. 2001. Situation analysis of water quality in the Umtata River Catchment. Water SA, (27) Pp 467474.

Genthe, B. \& Steyn, M. 2008. Parliamentary Briefing Paper on Endocrine Disrupting Chemicals. Annexure "C" of CSIR Report No. CSIR/NRE/ $W R / I R / 2008 / 0079 / C$. Pretoria. Council for Scientific and Industrial Research (CSIR).

Gleick, P.H. 1993. Water and Conflict. Fresh Water Resources and International Security, in International Security, Vol. 18, No 1, Summer 1993; 79-112.

Gleick, P.H. 1994. Water, War and Peace in the Middle East, in Environment, Vol. 36, No. 3; 7-15 \& 35-42.

Harding, W.R. \& Paxton, B.R. 2001. Cyanobacteria in South Africa: A Review. Water Research Commission Report No. TT 153/01. Pretoria: Water Research Commission.

Hattingh, H., Murray, K., Stassen, R. \& Van Wyk, J. (Eds). 2006. Resource Directed Management of Water Quality. Water Resource Planning Systems. Sub-Series No WQP 1. Pp 855. (Publication number: CSIR/ NRE/WR/ER/2006/0163/A).

Hattingh, J. \& Claassen, M. 2008. Securing Water Quality for Life. In Patrick, M.J., Rascher, J. \& Turton, A.R. (Eds.) Reflections on Water in South Africa, Special Edition of International Journal of Water Resource Development.. Vol. 24; No. 3. Pp. 401-417.

Hobbs, P. 2008. Parliamentary Briefing Paper on Acid Mine Drainage. Annexure "B" of CSIR Report No. CSIR/NRE/WR/IR/2008/0079/C. Pretoria. Council for Scientific and Industrial Research (CSIR).

Hodgson, F.D.I. \& Krantz, R.M. 1998. Groundwater quality deterioration in the Olifants River catchment above the Loskop Dam with specialized investigations in the Witbank Dam sub-catchment. Report No. 291/1/98. Pretoria: Water Research Commission.

Homer-Dixon, T.F. 1994. Environmental Scarcities and Violent Conflict: Evidence from Cases, in International Security, Vol. 19, No. 1; 5-40.

Homer-Dixon, T.F. 1999. The Myth of Global Water Wars. In Fleming, S. (Ed.) War and Water. Geneva: ICRC Publication Division.

Humpage, A.R., Hardy, S.J., Moore, E.J., Froscio, S.M. \& Falconer, I.R. 2000. Microcystins (cyanobacterial toxins) in drinking water 
enhance the growth of aberrant crypt foci in the colon. Journal of Toxicology and Environmental Health, 61: 101-111.

IPCS. 2002. Global Assessment of the State-of-the-Science of Endocrine Disruptors. WHO/PCS/EDC/002.2. The International Programme on Chemical Safety.

Ito, E., Kondo, F., Terao, K. \& Harada, K.-L. 1997. Neoplastic nodular formation in mouse liver induced by repeated intraperitoneal injection of microcystin-LR. Toxicon, 35: 1453-1457.

IWQS. 1999. Report on the Radioactivity Monitoring Programme in the Mooi River (Wonderfonteinspruit) Catchment. Report No. N/C22/00/RPQ/ 2399. Pretoria: Institute for Water Quality Studies.

Johnston, S. \& Bernstein, A. 2007. Voices of Anger: Protest and Conflict in Two Municipalities. Report to the Conflict and Governance Facility (CAGE). Johannesburg: The Centre for Development and Enterprise.

Johnston, N. \& Wolmarans, R. 2008. Xenophobic Violence Grips Johannesburg. Mail \& Guardian. 23 May 2008. http:// www.mg.co.za/articlePage.aspx?articleid=339509\&area=/ breaking_news/breaking_news__national/

Kempster, P.L., Van Vliet, H.R., Looser, U., Parker, I., Silberbauer, M.J. \& Du Toit, P. 1996. Overview of Radioactivity in Water Sources: Uranium, Radium and Thorium. Final Report, IWQS-No:N/0000/00/RPQ/0196. Pretoria: Institute for Water Quality Studies.

Kingwill, D.G. 1990. The CSIR: The First 40 Years. Pretoria: CSIR Information Services.

Mongillo, J. \& Booth, B. 2001. Environmental Activists. Westport, CT: Greenwood Publishing.

Murray, K. 2006. Resource Directed Management of Water Quality: Volume 1.2: Policy, in Hattingh, J., Stassen, R. and van Wyk, J. (Eds.) Water Resource Planning System Series, Sub-Series No. WQP 1.4.2, Edition 1. Pretoria: Department of Water Affairs and Forestry (DWAF).

Nishiwaki-Matushima, R., Nishiwaki, S., Ohta, T., Yoszawa, S., Suganuma, M., Harada, K., Watanabe, M.F. \& Fujiki, H. 1991. Structure-function relationships of microcystins, liver-tumour promoters, in interaction with protein phosphatase. Japanese Journal of Cancer Research, 82: 993-996.

NNR. 2007. Radiological Impacts of the Mining Activities to the Public in the Wonderfonteinspruit Catchment Area. Report No. TR-RRD-07-0006. (Also known as the Brenk Report). Pretoria: National Nuclear Regulator. 125 pp.

NWRS. 2004. National Water Resource Strategy. Pretoria: Department of Water Affairs and Forestry (DWAF). http://www.dwaf.gov.za/ Documents / Policies / NWRS / Default.htm

Oberholster, P. 2008. Parliamentary Briefing Paper on Cyanobacteria in Water Resources of South Africa. Annexure "A" of CSIR Report No. CSIR/ NRE/WR/IR/2008/0079/C. Pretoria. Council for Scientific and Industrial Research (CSIR). 
Oberholster, P.J., Botha, A-M. \& Cloete, T.E. 2005. An overview of toxic freshwater cyanobacteria in South Africa with special reference to risk, impact and detection by molecular marker tools. Biokemistri 17: 57-71.

Oberholster, P.J. \& Botha, A-M. 2007. Use of PCR based technologies for risk assessment of a winter cyanobacterial bloom in Lake Midmar, South Africa. African Journal of Biotechnology, 6: 14-21.

Oberholster, P.J. \& Ashton, P.J. 2008. State of the Nation Report: An Overview of the Current Status of Water Quality and Eutrophication in South African Rivers and Reservoirs. Pretoria: Council for Scientific and Industrial Research (CSIR).

Oberholster, P.J., Van Ginkel, C. \& Naidoo, S. 2008. Eutrophication: A national problem in South Africa. Vaalco Supplement.

Offringa, G., Mjoli, N., Venter, S.N., Kfir, R. \& Moolman, A. 2007. A New Strategic Framework for Water-Related Health Research. In Water SA. (33)5. Pp. 589 - 592.

Percival, V. \& Homer-Dixon, T. 1998. Environmental Scarcity and Violent Conflict: The Case of South Africa, in Journal of Peace Research. Vol, 35. No. 3.; Pp 279-298.

Percival, V. \& Homer-Dixon, T. 2001. The Case of South Africa, in Diehl, P.F. \& Gleditsch, N.P. (Eds.) Environmental Conflict. Boulder: Westview Press. Pp. 13 - 35.

Power, M. 2008. CSIR Suspends Top Water Scientist. The Times. 23 November 2008. Available online at http://www.thetimes.co.za/ PrintEdition/Insight/Article.aspx?id=890387.

Pitois, S., Jackson, M.H. \& Wood, B.J.B. 2000. Problems associated with the presence of cyanobacteria in recreational and drinking water. International Journal of Environmental Health Research, 10: 203218.

Rascher, J., Ashton, P.J. \& Turton, A,R. 2009. The Strategic Role of Water in Alleviating the Human Tragedy Associated with HIV/AIDS in Africa. In Biswas, A.T. \& Tortajada, C. Eds. Water Management in 2020 and Beyond. Berlin: Springer Verlag.

Republic of South Africa (RSA). 1970. Report of the Commission of Inquiry into Water Matters. Pretoria: Government Printers. Doc. No. R.P. $34 / 1970$.

Sibanda, B. 2008. Falling Economic Standards Cause Xenophobia in South Africa. Afrik.com. 14 May 2008. http://en.afrik.com/ article $13586 . \mathrm{html}$

Slabbert, J. L., Venter, E. A., Moletsane, M., van Wyk, J. H., Schillack, V., Aneck-Hahn, N. H. \& Marais, P. 2007(a). An investigation into the occurrence of steroidal hormones (estrogens) in sewage effluent using biological/biochemical and chemical techniques: 2003-2005. In Burger, A.E.C. (Ed.), 2007. Implementation of a Research Programme for Investigating Endocrine Disrupting Contaminants in South African Water Systems. Vol. 2, Appendix 3C. WRC Report No. 1402/1/07. Pretoria. v + 20 pages. 
Slabbert, J. L., Venter, E. A., Moletsane, M., van Wyk, J. H., Blaise, C. \& Aneck-Hahn, N. H. 2007(b). An investigation of the estrogenic activity in water from selected drinking water treatment processes. Report to the Water Research Commission by CSIR Natural Resources and the Environment. Report Number 1532/ 1/07. xvii +52 pages.

Smillie, S. 2008. Tooth Fairy Project May Reveal Effect of Uranium. The Star, 18/3/2008, pp. 10.

Snaddon, C.D., Davies, B.R. \& Wishart, M.J. 1999. A Global Overview of Inter-Basin Water Transfer Schemes, with an Appraisal of their Ecological, Socio-Economic and Socio-Political Implications, and Recommendations for Their Management. Water Research Commission Report No. TT120/00. Pretoria: Water Research Commission.

Swyngedouw, E. 1999. Modernity and Hybridity: The Production of Nature: Water and Modernization in Spain. Paper presented to the Water Issues Study Group, SOAS, University of London, 25 January 1999.

Swyngedouw, E. 1999. Hybrid Waters: On Water, Nature and Society, in the Proceedings of the Conference "Sustainability, Risk and Nature: The Political Ecology of Water in Advanced Societies" that was held at Oxford University on 15-17 April 1999.

Tempelhoff, E. 2007. Gifspruit (Poison Stream). Beeld Newspaper. 3 February, 2007.

Tempelhoff, E. 2008. Gifstof in Kos Skok: Radioaktiewe Stowwe in Voedselketting (Toxins in Food Shock: Radioactive Substances in Food Chain). Beeld Newspaper. 1 February, 2008.

Tenner, E. 1996. Why Things Bite Back: Technology and the Revenge of Unintended Consequences. New York: Knopf.

Toens, P. D., Stadler, W. \& Wullschleger, N. J. 1999. The Association of Groundwater Chemistry and Geology with Atypical Lymphocytes (as a Biological Indicator) in the Pofadder Area, North Western Cape, South Africa. Water Research Commission, Report Number: 839/1/98. Pretoria: Water Research Commission. 141 pages.

Turton, A.R. 2008(a). Three Strategic Water Quality Challenges that DecisionMakers Need to Know About and How the CSIR Should Respond. CSIR Report No. CSIR/NRE/WR/EXP/2008/0160/A. Keynote address, A Clean South Africa, presented at the CSIR Conference "Science Real and Relevant", 18 November 2008. Pretoria: Council for Scientific and Industrial Research (CSIR). Available online at http: / / www.bosparra.com/wp-content/uploads / 2008/11/ banned_csir2008.pdf

Turton, A.R. 2008(b). Three Strategic Water Quality Challenges that Parliamentarians Need to Know About. CSIR Report No. CSIR/NRE/ WR/IR/2008/0079/C prepared for the October Parliamentary Briefing. Pretoria: Council for Scientific and Industrial Research (CSIR).

Turton, A.R. 2009. South African Water and Mining Policy: A Study of Strategies for Transition. In Huitema, D. \& Meijerink, S. (Eds.) Water Transitions. Netherlands: Edgar Elger. 
Turton, A.R., Meissner, R., Mampane, P.M. \& Seremo, O. 2004. A Hydropolitical History of South Africa's International River Basins. Report No. 1220/1/04 to the Water Research Commission. Pretoria: Water Research Commission.

Turton, A.R., Patrick, M.J. \& Rascher, J. 2008(a). Setting the Scene: Hydropolitics and the Development of the South African Economy. In Patrick, M.J., Rascher, J. \& Turton, A.R. (Eds) Reflections on Water in South Africa, Special Edition of International Journal of Water Resource Development. Vol. 24; No. 3. Pp. 319-323.

Turton, A.R., Ashton, P.J. \& Jacobs, I. 2008(b). The Management of Shared Water Resources in Southern Africa. CSIR Report No. CSIR/NRE/ WR/ER/2008/0400/C. IMIS Contract No. 2009UNA073263853111. Lusaka: United Nations Economic Commission for Africa Southern Africa (UNECA-SA).

Ueno, Y., Nagata, S., Tsutsumi, T., Hasegawa, A., Watanabe, M.F., Park, H.D., Chen, G.C. \& Yu, S. 1996. Detection of microcystins, in bluegreen alga, hepatotoxin in drinking water sampled in Haimen and Fusui, endemic areas of primary liver cancer in China, by highly sensitive immunoassay. Carcinogenesis, 17: 1317-1321.

Van Vuuren, L. 2008. Eutrophication: Microscope Refocused on SA Water Quality Threat. Water Wheel. (7)5 Pp. $14-17$.

Wade, P.W., Woodbourne, S., Morris, W.M., Vos, P. \& Jarvis, N.W. 2002. Tier 1 Risk Assessment of Selected Radionuclides in Sediments of the Mooi River Catchment. WRC Project No. K5/1095. Pretoria: Water Research Commission.

Walwyn, D. \& Scholes, R.J. 2006. The Impact of a Mixed Income Model on the South African CSIR: A Recipe for Success or Disaster? In South African Journal of Science. (102) Pp. 239-243.

Winde, F. 2005. Impacts of Gold-mining Activities on Water Availability and Quality in the Wonderfonteinspruit Catchment. In Coetzee, H. (Ed.) An Assessment of Current and Future Water-pollution Risk with Application to the Mooirivierloop (Wonderfonteinspruit). WRC Report No. K5/1214. Pp 14-38. Pretoria: Water Research Commission.

Wolf, A.T. 1998. Conflict and Cooperation along International Waterways, in Water Policy (1); 251-265.

Wolf, A.T. 1999. Water Wars and Water Reality: Conflict and Cooperation Along International Waterways, in Lonergan, S. (Ed.) Environmental Change, Adaptation, and Human Security. Dordrecht: Kluwer Academic. Pp. 251-265.

Wolf, A.T. 2006. Hydropolitical Vulnerability and Resilience: Series Introduction. In Wolf, A.T. (Ed.). Hydropolitical Vulnerability and Resilience along International Waters: Africa. Nairobi: United Nations Environment Program (UNEP). Pp. 3 - 17.

Wolf, A.T., Yoffe, S.B. \& Giordano, M. 2003. International Waters: Identifying Basins at Risk, in Water Policy, Vol. 5, No. 1; 29-60.

WSE. 2008. Endocrine Disruptors - a real threat? Water Sewage and Effluent. (28)5. September 2008. Pp. $24-27$. 